\title{
Training, task flexibility and low skilled workers' employability
}

Citation for published version (APA):

Sanders, J. M. A. F., \& de Grip, A. (2003). Training, task flexibility and low skilled workers' employability. Researchcentrum voor Onderwijs en Arbeidsmarkt, Faculteit der Economische Wetenschappen. ROA Research Memoranda No. 6E https://doi.org/10.26481/umaror.200306E

Document status and date:

Published: 01/01/2003

DOI:

10.26481/umaror.200306E

Document Version:

Publisher's PDF, also known as Version of record

\section{Please check the document version of this publication:}

- A submitted manuscript is the version of the article upon submission and before peer-review. There can be important differences between the submitted version and the official published version of record.

People interested in the research are advised to contact the author for the final version of the publication, or visit the DOI to the publisher's website.

- The final author version and the galley proof are versions of the publication after peer review.

- The final published version features the final layout of the paper including the volume, issue and page numbers.

Link to publication

\footnotetext{
General rights rights.

- You may freely distribute the URL identifying the publication in the public portal. please follow below link for the End User Agreement:

www.umlib.nl/taverne-license

Take down policy

If you believe that this document breaches copyright please contact us at:

repository@maastrichtuniversity.nl

providing details and we will investigate your claim.
}

Copyright and moral rights for the publications made accessible in the public portal are retained by the authors and/or other copyright owners and it is a condition of accessing publications that users recognise and abide by the legal requirements associated with these

- Users may download and print one copy of any publication from the public portal for the purpose of private study or research.

- You may not further distribute the material or use it for any profit-making activity or commercial gain

If the publication is distributed under the terms of Article $25 \mathrm{fa}$ of the Dutch Copyright Act, indicated by the "Taverne" license above, 


\title{
Training, Task Flexibility and Low-Skilled Workers' Employability
}

\author{
ROA-RM-2003/6E
}

Jos Sanders, Andries de Grip

Research Centre for Education and the Labour Market

Faculty of Economics and Business Administration

Maastricht University

Maastricht, July 2003 
ISBN 90-5321-375-9

Sec03.116.doc 


\section{Contents}

Abstract

Acknowledgement

1 Introduction

2 Training, task flexibility and the concept of Employability

3 Data 5

3.1 Expected labour market position in five years

5

4 Estimation results

8

5 Conclusions and discussion

References

Appendix A 



\begin{abstract}
In this paper we analyse whether the training participation and task flexibility of low-skilled workers contribute to their firm-internal and external mobility. We find that both workers' training participation and task flexibility merely contribute to workers' firm-internal employability. However, the workers' participation in training plays a much more explicit role in workers' firm-internal careers than their task flexibility as it appears to be an important means to enhance their opportunities on the firm-internal labour market.

Both workers' participation in training and their task flexibility do not contribute to the external employability of the low-skilled workers. Task flexible low-skilled workers even less often expect to be externally employable than non-task flexible workers. The focus of low-skilled workers on their firm-internal employability can be explained by the fact that they usually have more opportunities to improve their position in the firm-internal labour market than on the external labour market.
\end{abstract}

\title{
Acknowledgement
}

The authors thank Bart Golsteyn and Patrick van Eijs for their helpful comments on an earlier version of this paper. 



\section{Introduction}

In the 1990's workers' employability has gained much interest of both policy makers and Human Resource specialists in the business community. The paradigm of lifetime employment seems to be replaced by a new paradigm of lifetime employability marked by a high degree of flexibility. Among others Arthur (1994), Bridges (1994) and Hyatt (1995) have characterised modern careers as boundaryless. We will consider employability to be an individual characteristic in terms of a worker's capacity and willingness to remain attractive in the labour market, i.e. a worker's labour market value. This raises the question to what extent workers can maintain or increase their employability in the labour market. In the literature on employability two instruments are frequently mentioned: training participation and task flexibility (i.e. doing tasks that belong to other jobs). These "employability instruments" may contribute to workers' ability to remain attractive in the labour market and also signal a worker's willingness to be employable (cf. De Grip et al., 2004).

In this paper we will test the hypothesis that training participation and task flexibility contribute to the employability of low-skilled workers. In this analysis we will distinguish between three forms of employability. Job-match employability refers to workers' chance to remain employed in their current job within their current firm (same job, same employer), whereas firm-internal employability refers to workers' chance to switch to another job within their current firm and external employability refers to workers' chance to switch to a job in another firm. Although the term job-match employability indicates that participation in training and task flexibility might also be important for low-skilled workers to keep up with the developments in the contents of their current jobs, we expect that both training and task flexibility are more important for their firm-internal and external employability.

Our focus on low-skilled workers is interesting from two points of view. First, the labour market position of low-skilled workers is vulnerable nowadays as their employability is threatened because they are frequently crowded-out of their traditional job domains by higher skilled workers (Borghans \& De Grip, 2000). Second, low-skilled workers generally participate less often in training than skilled workers (e.g. Shields, 1998), so one might wonder whether or not low-skilled workers deliberately invest in their employability. 
We first analyse whether workers' participation in training and task flexibility affect lowskilled workers' expectations on their employability in terms of the three forms of employability we distinguish. Second, we analyse whether these expectations are realised in the near future. Finally, we analyse whether low-skilled workers' employability expectations induce a larger participation in training and task flexibility. This enables us to analyse whether low-skilled workers participate in training and demonstrate their task flexibility to enhance their chance to realise their expectations.

For our analyses we use data from the linked 1998 and 2000 waves of the Dutch OSA Labour Force Survey. We find that both workers' training participation and task flexibility merely contribute to workers' firm-internal employability. However, workers' participation in training plays a much more explicit role in workers' firm-internal careers than their task flexibility as the participation in training appears to be an important tool to enhance their opportunities on the firm-internal labour market. Both workers' participation in training and their task flexibility do not contribute to the external employability of the low-skilled workers. Task flexible low-skilled workers even less often expect to be externally employable than non-task flexible workers.

The article is organised as follows. In section 2 we discuss the development of the concept of employability in the second half of the $20^{\text {th }}$ century. From this discussion we derive the three forms of employability we distinguished in our empirical analysis. In section 3 we discuss the data used and we present a descriptive overview of low-skilled workers' expected job match, firm internal and external employability in the Netherlands. Section 4 discusses the three analyses on the relation between training participation, task flexibility and workers' employability. Section 5 concludes.

\section{Training, task flexibility and the concept of Employability}

The concept of workers' employability is not a new concept. ${ }^{1}$ It has been developed in the 1950's. However, there have been some changes in the focus of the concept in the course of time. In the 1950's and 1960's employability was seen as an individual's potential to become employed. The attention focused on a worker's attitude regarding employment in general and

1. See De Grip et al. (2004) for a more comprehensive overview of the literature on employability. 
towards the self-perception workers develop during their careers. Influencing and adjusting attitudes and the perception people have of their abilities contributed to successful labour market re-entry of people who lost their self-confidence (Soloff \& Bolton, 1969).

From 1970 onwards, attention became increasingly focused on occupational knowledge and skills instead of a worker's attitudes. Not only basic occupational skills, but also knowledge about one's possibilities (Tseng, 1972), knowledge about one's own position in the labour market (Mangum, 1976) and knowledge about the employment situation in general play crucial roles here. During the end of the 1970's, partly related to the economic recession in the industrialised countries, it was realised that merely having some occupational skills is often not sufficient to remain attractive in the labour market. Hoyt (1978) acknowledged the importance of a worker's 'transferable' skills, which retain their value in many different work situations. Examples of these transferable skills are social and relational skills that are not only important to get a job, but also to keep it and move on to another job, if necessary. Moreover, from an employee's point of view, employability became more important, since the economic recession made it harder to find and keep a job.

After 1980, the employability concept more and more became a meta-characteristic of workers' labour market value. This meta-characteristic combines attitudes, knowledge and skills and determines the labour market potential of workers. In this sense employability has an important influence on a worker's career, whether it is in the beginning, building, or final stage (Charner, 1988).

In the 1990's the differences between the various views on employability and how it effects people increased. For some authors, only a worker's labour market potential and skills play a role. Others focus on the possibilities to use a worker's employability in organisations (Levy et al., 1992), knowledge of the labour market and policies of firms and the government (Outin, 1990), or emphasize workers' capacity to influence their careers (Bloch \& Bates, 1995) and to deal with changes (Hyatt, 1995).

In order to structure the employability concept, Thijssen (1998) developed a taxonomy of the existing employability definitions. He distinguishes between three types of employability definitions: A core definition, a broader definition, and an all-embracing definition. 
According to the core definition, employability encompasses all individual possibilities to be successful in a diversity of jobs in a given labour market situation. In its core definition, employability only deals with someone's capacities.

The broader definition of employability incorporates both the capacity and the willingness to be successful in a diversity of jobs. In addition, the ability to learn is included as an asset of a worker's employability. Therefore, in the broader definition, employability encompasses all individual characteristics that determine the current and the future position in the labour market. In the all-embracing definition, contextual factors and effectuation conditions are added. Effectuation conditions are context-bound factors that facilitate or hamper a worker's employability, such as e.g. the training provided by the firm. In the all-embracing definition, employability encompasses all individual and contextual conditions that determine a worker's current and future position on the labour market. However, the emphasis is still on workers' capacities and willingness to be pro-active, which gives them a strong position in the labour market. In this paper we therefore define a worker's employability as:

The capacity as well as the willingness to be and to remain attractive in the labour market, by anticipating on changes in tasks and work environment and pro-acting on these changes.

It should be emphasised that employability is not a static concept as a worker's employability can change over time. Whether or not workers are employable in the sense that they are able and willing to remain employed, depends upon a number of factors, some of which workers can and some of which they cannot (easily) influence directly. In this paper we focus on two important factors that can be influenced by the workers themselves, namely their training participation and task flexibility. ${ }^{2}$ As mentioned in the introduction, we aim to analyse whether the training participation and task flexibility of low-skilled workers contribute to their firm-internal and external employability. In these analyses it is important, however, to distinguish between the different ways in which workers can remain attractive for the labour market. For instance Groot \& Maassen van den Brink (2000) distinguish between workers' internal and external employability. External employability refers to the ability and willingness to switch to a similar or another job in another firm and therefore reflects the

2. The extent to which workers can determine their training participation and task flexibility of course also depends on the 'effectuation conditions' offered to them. 
value of workers' human capital on the external labour market. Internal employability refers to a worker's ability and willingness to remain employed with their current employer, i.e. the value of a worker's human capital in the internal labour market. Here we further distinguish between two groups of internally employable workers: those who remain employed in the same job and those who change jobs within the current firm. We therefore distinguish between three forms of employability: Job-match employability refers to workers who remain employed in their current job within their current firm. Firm-internal employability refers to workers who switch to another job within their current firm. External employability refers to workers who switch to a job in another firm.

\section{Data}

The data we used for our empirical analysis are taken from the linked 1998 and the 2000 waves of the Dutch OSA Labour Supply Survey. For 1998 the total sample size is 4,780 observations. For 2000 the total sample size is 4,185 . For the empirical analysis in this paper we selected the lower educated workers (ISCED 0-2) in the age between 16 and 50 who are in paid employment at the time of the interview in 1998, who have a permanent contract in 1998 and who participated in the surveys of both 1998 and $2000{ }^{3}$ This reduces the total sample size to 474 observations. Of these 474 persons, 92 work in manufacturing and 158 work in the services sector. The persons remaining work in other sectors such as agriculture and fisheries, education or health.

\subsection{Expected labour market position in five years}

We indicate the perceived employability of low-skilled workers in the Netherlands, by the labour market position they expect to have in five years. For this indicator we used the following question in the 1998 survey:

3. We excluded the workers who are older than 50 years since in the Netherlands these workers have a fair chance that within 5 years they will leave the labour market. Moreover, we excluded workers with a temporary contract because these workers will almost automatically leave their current job in the next few years, whereas this does not reflect a strong labour market position as is shown in Van Loo et al., (2001). 
On this question the following 8 answering categories were possible:

Working in a similar job in this firm, (Job-match employability)

Working in a different job in this firm, (Firm-internal employability)

Working in a similar job in another firm, (External Employability)

Working in a another job in another firm, (External Employability)

Unemployed,

Resigned,

Disabled/ unable to work,

Retired,

Don't know.

This indicator clearly indicates workers' expectations of their future labour market position.

Table 1 shows that practically all low-skilled workers think they will remain active in the labour market for the next five years. Only about $2 \%$ expects to be without a job in five years. In this sense it can be concluded that the low-skilled workers in the Netherlands who have permanent contracts are rather optimistic about their overall (internal as well as external) employability. Table 1 also shows that the greater part of the low-skilled workers expects to be working in their current or a similar job within the current firm five years from now (73\%). $15 \%$ of the workers expects to change jobs within the current firm and about one in ten expects to leave their current firm to start working somewhere else. This indicates that the great majority of the low-skilled workers rely on their firm-internal labour market.

Table 1 also shows that workers in the age between 16 and 34 more often than older workers expect to leave their current job within the next five years. More than $80 \%$ of the $45-50$ year old workers expect not to leave their current job within five years, compared to $60 \%$ of the youngest categories of workers. This probably reflects the job search process in the beginning of workers' careers (cf. Topel and Ward, 1992 and Neil, 1999). It also reflects the idea that older workers are less mobile than their younger colleagues, either because of a higher rate of firm-specific human capital or a stronger aversion to change among older workers (Becker, 1964; Salthouse, 1991), or because of the fact that employers who recruit new workers would rather invest in a younger worker's human capital than in that of an older worker (Gallup, 1990). The table also shows that low-skilled workers that are employed in services more often expect to be firm-internally employable than the low-skilled workers in manufacturing. 


\begin{tabular}{|c|c|c|c|c|c|}
\hline & $\begin{array}{l}\text { Job match } \\
\text { employable }\end{array}$ & $\begin{array}{c}\text { Firm } \\
\text { internally } \\
\text { employabl } \\
\text { e } \\
\%\end{array}$ & $\begin{array}{l}\text { Externally } \\
\text { employable }\end{array}$ & $\begin{array}{l}\text { Without } \\
\text { A job }\end{array}$ & Total \\
\hline Male & 73 & 16 & 9 & 1 & 66 \\
\hline Female & 74 & 14 & 9 & 4 & 34 \\
\hline $16-24$ years & 60 & 15 & 25 & & 5 \\
\hline 25-34 years & 61 & 21 & 15 & 3 & 23 \\
\hline $35-44$ years & 76 & 16 & 8 & 1 & 47 \\
\hline $45-50$ years & 82 & 10 & 4 & 4 & 25 \\
\hline Elementary job & 68 & 21 & 9 & 2 & 14 \\
\hline Lower level job & 79 & 13 & 6 & 2 & 47 \\
\hline Middle or higher level job & 67 & 11 & 19 & 3 & 39 \\
\hline Manufacturing & 80 & 10 & 9 & 1 & 21 \\
\hline Services & 72 & 19 & 7 & 3 & 36 \\
\hline Else & 70 & 16 & 12 & 2 & 52 \\
\hline Task flexible & 73 & 20 & 6 & 2 & 67 \\
\hline Not task flexible & 75 & 4 & 17 & 4 & 33 \\
\hline Satisfied & 79 & 10 & 6 & 1 & 92 \\
\hline Unsatisfied & 30 & 11 & 43 & 5 & 8 \\
\hline Overtime & 72 & 18 & 8 & 2 & 45 \\
\hline No overtime & 75 & 13 & 10 & 2 & 55 \\
\hline Training & 73 & 16 & 8 & 2 & 71 \\
\hline No training & 73 & 13 & 12 & 2 & 29 \\
\hline Part-time & 80 & 11 & 7 & 2 & 27 \\
\hline Full-time & 72 & 17 & 9 & 2 & 73 \\
\hline Total & 73 & 15 & 9 & 2 & 100 \\
\hline
\end{tabular}

Source: OSA

Low-skilled workers who are doing tasks that are not part of their job expect to change jobs within their current firm considerably more often than workers who are not task flexible. Non-task-flexible workers on the other hand expect to leave their current firm far more often than task-flexible workers. This suggests that low-skilled workers signal their task flexibility in order to enhance their firm-internal employability. The same goes, however to a far lesser 
degree, for low-skilled workers who participate in training. Of these workers $16 \%$ thinks that they will switch to another job within their current firm within the next five years, compared to $13 \%$ of the low-skilled workers who do not participate in training. More striking, however, is that whether or not low-skilled workers participate in training does not affect their expectations to stay or leave their current job. Moreover, it shows that more than a fifth of the low-skilled workers do not have the idea that it is important for them to participate in training in order to reduce the risk of losing one's job due to skill obsolescence (cf. De Grip \& Van Loo, 2002).

Furthermore, table 1 shows that workers who are not satisfied in their job obviously expect to leave their job far more often than workers who are satisfied. It is surprising, however, that no less than $30 \%$ of the low-skilled workers who are not satisfied still expect to remain employed in their current job with their current employer for another five years. This suggests that these workers might feel insecure about their labour market value or that they even feel 'stuck' in their current position, which might contribute to their dissatisfaction. The data also show that $43 \%$ of the workers who are not satisfied with their current job expects to leave the firm where they work, whereas only $11 \%$ expects 'just' to change to another job in the firm-internal labour market. This suggests that workers' dissatisfaction is more often related to the firm as a whole than just to their job.

Finally, table 1 shows that low-skilled workers who have full-time contracts less often expect to remain employed in their current job than those who work part-time. This is quite surprising as one might expect that workers who have a part-time contract feel less secure about their job than those who have a full-time contract. However, since our data only refer to workers with permanent contracts one might also interpret this finding as a confirmation of the idea that part-timers who prefer to work part-time in order to combine work and care will opt for job security and are probably less mobile in the labour market.

\section{Estimation results}

In this section we will analyse whether the training participation and task flexibility of lowskilled workers affect their firm-internal or external employability. First, we will show the 
estimation results of a multinomial logit analysis on the effects of the training participation and task flexibility of low-skilled workers on their employability expectations, in terms of the three types of employability we distinguish: job-match employability, firm-internal employability and external employability. Next, we will analyse whether the expectations workers had in 1998 were realised in 2000 , by performing a multinomial logit analysis on the actual changes in the labour market position of low-skilled workers during the 1998-2000 period. Finally, we will analyse whether workers' employability expectations in 1998 affected their training participation and task flexibility during the 1998-2000 period. These two binomial logit analyses enable us to show whether or not low-skilled workers invest in training and demonstrate their task flexibility in order to enhance the chance to realise their employability expectations.

The determinants of low-skilled workers' employability expectations

We first analyse whether the employability expectations the low-skilled workers had in 1998 are affected by their training participation and task flexibility in the two years before the expression of the expectations. For this analysis we use the following two independent variables:

- Training: Participation in courses (1994-1998)

- Task flexibility: Performed tasks outside one's job (1996-1998)

Moreover, we include three (dummy) variables that indicate the quality of the job low-skilled workers have:

- Whether a worker is satisfied in his or her current job

- Whether a worker works overtime

- Whether a worker has a part-time contract

and we include a number of covariates, namely: gender, age, sector of industry, professional level and tenure.

The estimation results in table 2 show that whether or not a low-skilled workers participated in training between 1994 and 1998 does not affect the perceptions of their employability.

4. We here had to use data for the period 1994-1998 as we did not have the data for the period 19961998 only. 
Neither the chance of workers expecting to change jobs within their current firm or the chance of workers expecting to leave their current firm entirely are affected by previous training participation.

Table 2

Multinomial logit estimation of low-skilled workers' self-assessed employability (reference category: same job, same firm in five years)

Standard Error

\section{External employability}

Intercept

1.66

1.05

Training

0.16

0.51

Task flexibility

$-1.24$

0.44

Satisfaction

$-2.50$

0.57

Overtime

0.51

0.45

Part-time

0.31

0.67

Male

$1.20 *$

0.71

Age

$-0.48 *$

0.26

Elementary level job

Lower level job

REF

$-1.47 *$

REF

Middle or higher level job

$-0.64$

0.64

Manufacturing sector

$-0.25$

0.62

Services sector

$-0.20$

0.53

Tenure

$-0.07 *$

0.53

0.04

Firm-internal employability

Intercept

$-1.09$

1.03

Training

0.33

0.38

Task flexibility

1.78

0.55

Satisfaction

$-1.37$

0.57

Overtime

0.21

0.32

Part-time

$-0.67$

0.51

Male

$-0.23$

Age

$-0.65$

0.46

Elementary job

REF

0.22

Lower level job

0.33

REF

Middle or higher level job

0.80

0.57

Manufacturing sector

$-0.71$

0.58

Services sector

0.68

0.45

Tenure

$-0.02$

0.36

0.03

\begin{tabular}{lr}
\hline $\mathbf{- 2}$ Log-Likelihood= & 449.26 \\
$\chi^{2=}$ & 92.84 \\
$\mathbf{N}=$ & 379 \\
$\mathbf{D f}=$ & 24 \\
\hline$* *$ Significant at $5 \%$ level. & \\
$*$ Significant at the $10 \%$ level & \\
\hline
\end{tabular}


Task flexibility, however, rather strongly affects workers' employability. Task flexible workers expect that they will change jobs within their current firm rather than remain employed in their current job but expect to have a smaller chance to leave their current firm than to remain employed in their current job. This suggests that workers who perform tasks that are no part of their job have the idea that this contributes to their chance to move to another job in the firm-internal labour market.

Table 2 also shows that lower skilled workers who work in low level jobs (i.e. above the elementary level) expect to leave their current job and firm within five years less often than workers in the elementary jobs. This indicates that low-skilled workers with a 'low-level' job have a higher job-match employability than the low-skilled workers that are employed in the elementary jobs.

Table 2 also shows that there is a strong negative relationship between workers' job satisfaction and their firm-internal employability expectations. However, the negative relationship between job satisfaction and the chance of a worker expecting to leave the firm entirely is even stronger. We may conclude therefore that dissatisfied workers often expect to leave the firm where they work entirely and not just their current job.

Low-skilled workers who are employed in the services sector more often expect to change jobs within their current firm. This indicates that the low-skilled workers that are employed in the service sectors have a relatively high firm-internal employability.

Table 2 also shows that the older workers are the less likely it is that they expect to leave their current job or their current firm within the next five years. Older workers apparently gradually put less trust into their external and firm-internal employability. They trust mainly on remaining employed in their current job. Tenure adds to these findings. The longer workers have worked in their current job, the less likely it is that they expect to be externally employable. However, tenure has no significant effect on whether or not a worker expects to change jobs within the firm. Finally, male workers more often expect to leave their current firm within the next five years than female workers do. 
In order to answer the question whether or not workers' medium-term employability expectations in 1998 have already been realised in $2000^{5}$, we analysed the determinants of the actual changes in the workers' labour market position in the 1998-2000 period by means of a multinomial logit analysis. The dependant variable in this analysis is the effectuation of a worker's employability in the first two years, in which we again distinguish between a worker's firm-internal employability, external employability and as a reference the job-match employability.

In order to analyse whether the changes in a worker's labour market position are in accordance with their employability expectations we use the following independent variables:

- Employability Expectation: Expected labour market situation in five years

- job-match employability

- firm-internal employability

- external employability (1998)

- Training 1994-1998: Participation in courses (1994-1998)

- Training 1998-2000: Participation in courses (1998-2000)

- Task flexibility 1996-1998: Performed tasks outside own job (1996-1998)

- Task flexibility 1998-2000: Performed tasks outside own job (1996-1998)

Moreover, as in our first analysis, we include the variables on workers' job satisfaction, overtime work, part-time work and the covariates gender, age, sector of industry, job level and tenure (all variables refer to the situation in 1998).

Table 3 shows that low-skilled workers who in 1998 expected to move to another job within the firm where they were employed were indeed significantly more often employed in another job within the firm by the year 2000. This indicates that workers expectations on their firm-internal employability were realistic. However, low-skilled workers who considered themselves externally employable in 1998 also changed jobs within the firm significantly more often than workers who expected to remain in the same job. Surprisingly, the workers

5. We do not have the data to analyse this relation for a longer period. 
Table 3

Multinomial logit estimation of low-skilled workers' employability effectuation (reference category: job-match employability, i.e. no changes)

Standard Error

\section{External employability}

Intercept

1.32

0.93

Expected firm-internal employability

0.45

0.45

Expected external employability

0.85

0.52

Expected job-match employability

$\mathrm{REF}$

REF

Training 1994-1998

0.01

0.37

Training 1998-2000

$-0.07$

0.32

Task flexibility 1996-1998

$-0.17$

0.35

Task flexibility 1998-2000

$-0.30$

0.33

Satisfaction

$-0.79$

0.56

Overtime

0.07

0.32

Part-time

0.17

0.45

Male

$-0.73$

0.44

Age

$-0.11$

0.20

Elementary job

REF

REF

Lower level job

$-0.03$

0.47

Middle or higher level job

$-0.52$

0.50

Manufacturing sector

$-0.49$

0.42

Services sector

$-0.73 * *$

0.37

Tenure

$-0.12 *$

0.04

\section{Firm-internal employability}

Intercept

$-3.20 * *$

1.26

Expected firm-internal employability

$1.698 * *$

0.43

Expected external employability

$1.252 *$

0.63

Expected job-match employability

REF

REF

Training 1994-1998

$-0.67$

0.43

Training 1998-2000

$0.84^{* *} \quad 0.37$

Task flexibility 1996-1998

$-0.30$

0.44

Task flexibility 1998-2000

0.08

0.39

Satisfaction

0.21

0.70

Overtime

0.21

0.38

Part-time

0.42

0.53

Male

$-0.77$

0.51

Age

0.07

0.24

Elementary job

REF

REF

Lower level job

0.37

0.66

Middle or higher level job

0.77

0.66

Manufacturing sector

0.23

0.49

Services sector

0.22

0.42

Tenure

$0.06 * *$

0.02 
Table 3 (continued)

Multinomial logit estimation of low-skilled workers' employability effectuation (reference category: job-match employability, i.e. no changes)

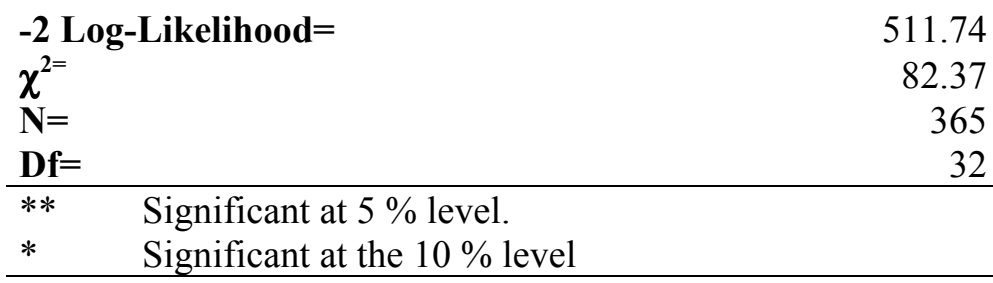

who in 1998 expected to leave the firm within 5 years did not leave the firm more often in the first two years than the workers who in 1998 expected to remain employed in their job for another 5 years. One possible explanation for these results is that finding a new job outside the firm is more difficult and at least takes more time than finding one inside the firm and that workers who consider themselves externally employable use inside options as an alternative for outside options that might be more difficult to realise.

Table 3 also shows that low-skilled workers who participate in training in the period 19982000 significantly more often move to another job within the firm. Since training participation in the period between 1994 and 1998 has no such effect, low-skilled workers probably mainly participate in training just before they change jobs internally, or even after the job change. ${ }^{6}$ Workers' task flexibility, however, does not have an additional effect on the extent to which low-skilled workers effectuate their employability.

Furthermore table 3 shows a significant negative effect of job tenure on the external employability of low-skilled workers and a significant positive effect of job tenure on workers' firm- internal employability. This indicates the firm-specific skills workers acquire in the course of their careers or the seniority rules in the internal labour market.

6. Our results confirm the results of De Grip et al. (1998) who find a direct relation (i.e. without taking account of workers' employability expectations) between workers' participation in training and their firm-internal mobility, whereas they did not find a correlation between workers' training participation and their external mobility. 
Finally, table 3 shows that male workers leave the firm where they work less often than female workers. Workers in the services sector have also left their firm less often than workers in other sectors of the economy. However, the low-skilled workers that are employed in services did not realise their higher firm-internal employability expectations.

The effect of workers' employability expectations on training participation and task flexibility

One may wonder whether low-skilled workers deliberately participate in training and demonstrate their task flexibility in order to enhance their chance to realise their firm-internal or external employability expectations. Therefore we analyse by means of two binomial logit analyses whether the employability expectations of low-skilled workers have any effect on their training participation or task flexibility.

Table 4

Binomial logit estimation of low-skilled workers' training participation and task flexibility (reference categories: no training and no task flexibility)

$\beta$

Standard Error

\begin{tabular}{|c|c|c|}
\hline Intercept & $-1.46 * *$ & 0.68 \\
\hline Expected firm-internal employability & $0.82 * *$ & 0.31 \\
\hline Expected external employability & 0.03 & 0.41 \\
\hline Expected job-match employability & REF & REF \\
\hline Training 1994-1998 & $0.91 * *$ & 0.27 \\
\hline Satisfaction & 0.23 & 0.45 \\
\hline Overtime & -0.04 & 0.23 \\
\hline Part-time & 0.36 & 0.36 \\
\hline Male & $0.72 * *$ & 0.35 \\
\hline Age & -0.22 & 0.14 \\
\hline Elementary job & REF & REF \\
\hline Lower level job & 0.17 & 0.37 \\
\hline Middle or higher level job & 0.12 & 0.38 \\
\hline Manufacturing sector & 0.21 & 0.29 \\
\hline Services sector & 0.18 & 0.27 \\
\hline Tenure & -0.01 & 0.02 \\
\hline
\end{tabular}

\begin{tabular}{lr}
\hline $\mathbf{- 2}$ Log-Likelihood $=$ & 494.68 \\
$\chi^{2=}$ & $32.98 * *$ \\
$\mathbf{N}=$ & 365 \\
$\mathbf{D f}=$ & 13 \\
\hline$* * \quad$ Significant at $5 \%$ level
\end{tabular}

** Significant at $5 \%$ level.

* $\quad$ Significant at the $10 \%$ level 
Table 4 (continued)

Binomial logit estimation of low-skilled workers' training participation and task flexibility (reference categories: no training and no task flexibility)

Standard Error

Task flexibility 1998-2000

Intercept

0.95

0.76

Expected firm-internal employability

0.14

0.35

Expected external employability

0.37

0.47

Expected job-match employability

REF

REF

Task flexibility 1996-1998

0.45

0.27

Satisfaction

0.28

0.48

Overtime

$-0.32$

0.25

Part-time

$-0.31$

0.38

Male

$-0.42$

0.38

Age

$-0.26$

0.16

Elementary job

REF

REF

Lower level job

0.63

0.39

Middle or higher level job

0.58

0.39

Manufacturing sector

0.26

0.33

Services sector

$-0.34$

0.28

Tenure

$-0.02$

0.02

\begin{tabular}{lr}
\hline $\mathbf{- 2}$ Log-Likelihood $=$ & 428.12 \\
$\chi^{2=}$ & 16.96 \\
$\mathbf{N}=$ & 365 \\
$\mathbf{D f}=$ & 13 \\
\hline$* *$ & Significant at $5 \%$ level
\end{tabular}

nificant at $5 \%$ level.

* $\quad$ Significant at the $10 \%$ level

Table 4 shows that low-skilled workers who expected to have a high firm-internal employability more often participate in training courses than workers who expected to remain employed in the same job and the workers who expected to have a high external employability. Since the low-skilled workers who participate in training more often move to another job in the firm-internal labour market than workers who do not participate in training (see table 3), we may conclude that low-skilled workers' training participation is indeed a vehicle by which they achieve to enhance their chance to realise their firm- internal employability expectations.

Table 4 also shows that the employability expectations of the low-skilled workers have no affect on their task flexibility. This indicates that low-skilled workers do not consider their 
task flexibility as a tool to enhance their chance to realise their employability expectations, although it might also be possible that they are hampered to signal their task flexibility in the jobs they have.

\section{Conclusions and discussion}

In this paper we analysed whether the training participation and task flexibility of low-skilled workers contribute to their firm-internal and external mobility. We found that both workers' training participation and task flexibility merely contribute to workers' firm-internal employability. However, the workers' participation in training plays a much more explicit role in workers' firm-internal careers than their task flexibility. Workers who demonstrate a large task flexibility indeed expect to have a large firm-internal employability. The latter, however, does not induce them to demonstrate their task flexibility more often, whereas their task flexibility also does not enhance the chance to realise their firm-internal employability expectations. On the other hand, workers' participation in training does not increase their firm-internal employability expectations. However, in practice the participation in training enhances a worker's chance to move to another job in the firm-internal labour market, whereas we also found that workers who think they are firm-internal employable are going to participate more often in training courses.

Both workers' participation in training and their task flexibility do not contribute to the external employability of the low-skilled workers. Task flexible low-skilled workers even less often expect to be externally employable than non-task flexible workers. This shows that low-skilled workers' task flexibility is merely a firm-internal employability enhancing practice that might reduce the scope of the low-skilled workers on their external opportunities in the labour market. The participation in training does not seem to play any role at all for workers' external employability, neither with respect to their perceptions, nor with respect to their actual external employability. These results can probably be explained by the conclusions from De Grip \& Wolbers (2002) who found that low-skilled workers usually have more opportunities to improve their position in the firm-internal labour market than on the external labour market. This is also shown by our finding that the low-skilled workers 
who found themselves externally employable often moved to another job in the internal labour market instead of realising their external employability expectations.

\section{References}

Arthur, M. B. (1994), The boundaryless career: A new perspective for organizational inquiry. Journal of Organizational Behaviour, Vol. 15, 295-306.

Becker, G. (1964). Human capital. A theoretical and empirical analyis, with special reference to education. New York: National Bureau of Economic Research.

Bloch, S., \& Bates, T. (1995). Employability, your way to career success. London: Kogan Page.

Borghans, L. \& Grip, A. de (2000).Skills and low pay: upgrading or overeducation? In: Gregory, M., Salverda, W. \& Bazen, S. (eds.), Labour market inequalities, problems and policies of low wage employment in international perspective, Oxford: Oxford University Press, 198-223.

Bridges, W. (1994). Jobshift, how to prosper in a workplace without jobs. Reading (Mass.): Addison-Wesley.

Charner, I. (1988). Employability credentials: a key to successful youth transition to work. Journal of Career Development, Vol. 15, no.1, 30-40.

Dekker, R. Grip, A. de en Heijke, H. (2002). The effects of training and overeducation on career mobility in a segmented labour market, International Journal of Manpower, Vol. 23, no. 2, 106-125.

Doeringer, P. \& Piore, M. (1971). Internal labour markets and manpower analysis. Lexington: Heath.

Gallup, J.L.(1990). Ageism: the problem of the 1990's. London: Brookstreet Employment Bureau.

Grip, A. de, H. Heijke, E. Willems (1998). Training and mobility, Netherlands' Journal of Social Sciences, Vol. 34, no.1, 78-98.

Grip, A. de \& J. van Loo (2002), 'The Economics of Skills Obsolescence: A Review', in: A. de Grip, J. van Loo, K. Mayhew (Eds.), Understanding Skills Obsolescence, Research in Labor Economics, Vol. 21, Amsterdam/Boston: JAI Press, 1-26.

Grip, A. de, J. van Loo \& J. Sanders (2004), The Industry Employability Index: Taking account of Supply and Demand Characteristics, International Labour Review, Vol.143, no. 1 (forthcoming)

Grip, A. de \& Wolbers, M. (2002). Are low-skilled workers better of in countries where internal labour markets dominate? Maastricht: ROA (Mimeo).

Groot, W. \& Maassen van den Brink, H. (2000). Education, training and employability, Applied Economics, Vol. 32, 573-581. 
Hoyt, K. B. (1978). Employability: Are the schools responsible? New directions for education and work; Reassessing the link between work and education, 29-33.

Hyatt, C. (1995). Lifetime employability: How to become indispensable. New York: Mastermedia Limited.

Levy, J. M., Jessop, D.J., Rimmerman, A., \& Levy, P.H. (1992). Attitudes of Fortune 500 corporate executives toward the employability of persons with severe disabilities: A national survey. Mental Retardation, Vol. 30, no. 2, 67-75.

Loo, J. van, A. de Grip, M. de Steur (2001). Skills Obsolescence: Causes and Cures, International Journal of Manpower, Vol. 22, no. 1/2, 121-137.

Mangum, G. L. (1976). Employability, employment and income. Salt Lake City: Olympus.

Neil, D. (1999). The complexity of job mobility among young men, Journal of Labor Economics, 17, 237-261.

Outin, J. L. (1990). Trajectoires professionnelles et mobilité de la main-d'œuvre : La construction sociale de l'employabilité. Sociologie du travail, Vol. 32, no. 4, 469-489.

Salthouse, T.A. (1991). Theoretical perspectives on cognitive ageing. Hillsdale (NJ): Erlbaum.

Shields, M. (1998). Changes in the determinants of employer-funded training for full-time employees in Britain, Oxford Bulletin of Economics and Statistics, Vol. 60, 189-214.

Soloff, A., \& Bolton, B.F. (1969). The validity of the CJVS-scale of employability for older clients in a vocational adjustment workshop. Educational and psychological measurement, Vol. 29, 993-998.

Thijssen, J. G. L., (1997). Employability en employment: Terminologie, modelvorming en opleidingspraktijk. Opleiding en ontwikkeling, Vol. 10, no.10, 9-14.

Topel, R.H., \& M.P. Ward, (1992), Job mobility and the careers of young man, Quarterly Journal of Economics, Vol. 107, pp. 439-479.

Tseng, M. S. (1972). Self-perception and employability: A vocational rehabilitation problem. Journal of Counselling Psychology, Vol. 19, no. 4, 314-317. 



\section{Appendix A}

\begin{tabular}{|c|c|c|}
\hline Variable & Definition & $N$ \\
\hline External employability & Changed firms 1998-2000 & 90 \\
\hline Firm-internal employability & Changed jobs within the firm between 1998 and 2000 & 57 \\
\hline Job-match employability & $\begin{array}{l}\text { No changes in labour market position from } 1998 \text { until } \\
2000\end{array}$ & 316 \\
\hline Expected external employability & Expects to change firms within 5 years (1998) & 42 \\
\hline $\begin{array}{l}\text { Expected firm-internal } \\
\text { employability }\end{array}$ & $\begin{array}{l}\text { Expects to change jobs within current firm within } 5 \\
\text { years (1998) }\end{array}$ & 70 \\
\hline Expected job-match employability & $\begin{array}{l}\text { Expects to remain employed in the same job for } \\
\text { another } 5 \text { years (1998) }\end{array}$ & 332 \\
\hline Training 1994-1998 & Participated in training between 1994 and 1998 & 335 \\
\hline No training 1994-1998 & Did not participate in training between 1994 and 1998 & 139 \\
\hline Training 1998-2000 & Participated in training between 1998 and 2000 & 203 \\
\hline No training $1998-2000$ & Did not participate in training between 1998 and 2000 & 271 \\
\hline Task flexibility 1996-1998 & $\begin{array}{l}\text { Performed tasks outside own job between } 1996 \text { and } \\
1998\end{array}$ & 325 \\
\hline No task flexibility 1996-1998 & $\begin{array}{l}\text { Did not perform tasks outside own job between } 1996 \\
\text { and } 1998\end{array}$ & 142 \\
\hline Task flexibility $1998-2000$ & $\begin{array}{l}\text { Performed tasks outside own job between } 1998 \text { and } \\
2000\end{array}$ & 318 \\
\hline No task flexibility $1998-2000$ & $\begin{array}{l}\text { Did not perform tasks outside one's own job between } \\
1998 \text { and } 2000\end{array}$ & 132 \\
\hline Satisfaction & (Highly) satisfied with one's job in 1998 & 435 \\
\hline No satisfaction & $\begin{array}{l}\text { Not that satisfied or not satisfied at all with job in } \\
1998\end{array}$ & 39 \\
\hline Overtime & $\begin{array}{l}\text { Worked extra hours, either paid or unpaid in } 1996 \text {, } \\
1997 \text { or } 1998\end{array}$ & 215 \\
\hline No overtime & Did not work extra hours in 1996, 1997 or 1998 & 259 \\
\hline Part-time & Worked 32 hours or less per week in 1998 & 116 \\
\hline Not part-time & Worked more than 32 hours per week in 1998 & 319 \\
\hline Male & Male & 311 \\
\hline No male & Female & 163 \\
\hline Age & Age in 1998 & $(474)$ \\
\hline Elementary job & Worked in an elementary job in 1998 & 65 \\
\hline Lower level job & Worked in a lower-level job in 1998 & 219 \\
\hline Middle or higher level job & Worked in a middle, higher or academic job in 1998 & 180 \\
\hline Manufacturing sector & Worked in the manufacturing sector in 1998 & 92 \\
\hline Services sector & Worked in the services sector in 1998 & 158 \\
\hline Else & Worked in another sector in 1998 & 135 \\
\hline Tenure & $\begin{array}{l}\text { Number of years a worker had worked in the same job } \\
\text { with the same employer in } 1998\end{array}$ & $(473)$ \\
\hline
\end{tabular}


